\title{
Greenhouse gas emissions from conventional and organic cropping systems in Spain. I. Herbaceous crops
}

\author{
Eduardo Aguilera • Gloria Guzmán • Antonio Alonso
}

Accepted: 10 November 2014 / Published online: 28 November 2014

(C) INRA and Springer-Verlag France 2014

\begin{abstract}
Agriculture is a major driver of climate change, particularly when all indirect emission sources are accounted for. Mitigation options targeted on one process are often proposed, ignoring their secondary effects on the overall greenhouse gas balance. Integrative methodologies such as life cycle assessment (LCA) are often applied without adjusting emission factors to specific site characteristics. Here, we used LCA to calculate the global warming potential of 38 pairs of organic and conventional herbaceous cropping systems and products in Spain. Crop products included rainfed cereals and pulses, rice, open-air vegetables, and greenhouse vegetables. We used data from farmer interviews and published conversion factors. Our results show that the emission balances were dominated by fossil fuel use rather than by direct field emissions. Organic management reduced crop emissions by $36-65 \%$, with the exception of rice showing an increase of $8 \%$ due to methane generation. Productbased emissions of organic crops were also lower by $30 \%$ on average, except for rice.
\end{abstract}

Keywords Life cycle assessment · Greenhouse gas emission · Mediterranean · Organic management · Carbon sequestration · Nitrous oxide $\cdot$ Coproduct allocation

\section{Introduction}

Agriculture is a major source of greenhouse gases and is also indirectly responsible for a large share of the greenhouse gases emitted in deforestation and other land use changes. Arable agriculture produces direct and indirect nitrous oxide $\left(\mathrm{N}_{2} \mathrm{O}\right)$

E. Aguilera $(\bowtie) \cdot$ G. Guzmán · A. Alonso

Agro-Ecosystems History Laboratory, Universidad Pablo de

Olavide, Carretera de Utrera, km. 1, 41013 Seville, Spain

e-mail: emagufer@upo.es emissions from nitrogen $(\mathrm{N})$ application to soils, methane $\left(\mathrm{CH}_{4}\right)$ from rice paddies, carbon dioxide $\left(\mathrm{CO}_{2}\right)$ from direct fossil energy use, and $\mathrm{N}_{2} \mathrm{O}$ and $\mathrm{CH}_{4}$ from open biomass burning. Further emissions occur due to fossil energy use in the production of agricultural inputs, particularly $\mathrm{N}$ fertilizers. Last, the other major link between agriculture and climate change is soil carbon (C) balance. Historical C losses from agricultural soils have contributed to the increase in both the global greenhouse gas budget and the vulnerability of agriculture to climate change (Lal et al. 2011), but they could be reversed by adequate agricultural practices.

Most mitigation practices can be applied in conventional and organic systems, but broad differences between both management types can be identified. Organic farming aims to reduce the environmental impact of agriculture by avoiding the use of synthetic compounds such as fertilizers and pesticides and by promoting practices such as crop diversification and organic fertilizers. Organic farmers thus prevent fossil energy emission associated to the industrial production of many inputs and promote soil $\mathrm{C}$ accumulation. Enhanced soil organic carbon (SOC) under organic management is supported by extensive experimental data in Mediterranean cropping systems (Aguilera et al. 2013a). In spite of this, lower yields could offset reductions in greenhouse gas emissions when quantified on product basis (Nemecek et al. 2011; Venkat 2012). Spain is the country with the largest surface under organic farming in the European Union (EU-25), with 1.65 Mha or $6.5 \%$ of total agricultural area (MAGRAMA 2011). The climate in Spain is mostly Mediterranean, with wet, mild winters and hot, dry summers. Herbaceous systems in Spain produce the majority of the local protein and high-value crops for export to nearby regions such as off-season vegetables. Rainfed cereals and legumes are cultivated in vast areas across the country with relatively low yields and low management intensities, occupying $5.36 \mathrm{Mha}$, or $83 \%$ of grain cultivated area, and producing $65 \%$ of the grain (MAGRAMA 2011). Vegetables 
represent one of the major agricultural commodities produced in Spain, with $44 \%$ of local production being exported according to FAOSTAT (FAO 2014). They are mostly cultivated under irrigation, and greenhouse systems represent $18 \%$ of the area, with yields usually doubling those of open-air horticulture (MAGRAMA 2011).

A number of papers studying greenhouse gases emissions in Mediterranean herbaceous systems have been published (e.g., Biswas et al. 2008; Venkat 2012; Theurl et al. 2013), although there is still a lack of information on some specific systems, such as rice paddies, and particularly of comprehensive comparisons between organic and conventional management. On the other hand, most agricultural life cycle assessment (LCA) studies employ Tier 1 IPCC $\mathrm{N}_{2} \mathrm{O}$ emission factors and/or do not account for $\mathrm{C}$ sequestration, despite soil processes represent a large share of the carbon footprint of agricultural systems and are associated to very high uncertainty (IPCC 2006). All this may result in inaccurate estimations of total global warming potential, as shown by different studies under Mediterranean conditions (Biswas et al. 2008; Venkat 2012). Another common gap in LCAs of crop products is the study of the effects of the alternative destinies of coproducts such as cereal straw, particularly of their use as animal feed, energy production, and soil application for carbon sequestration. This is a very relevant issue in a context of increasing interest for straw energy production (e.g., Cherubini and Ulgiati 2010; Nguyen et al. 2013).

Given the lack of precision of IPCC Tier 1 factors under Mediterranean climate and the difficulty of implementing intensive field measurements, there is a need to develop simple models able to estimate soil greenhouse gases emissions balances from management information in these areas. We had previously synthesized the current scientific information on climate-specific $\mathrm{N}_{2} \mathrm{O}$ emission factors and C sequestration responses to management practices under Mediterranean conditions in two meta-analyses (respectively, Aguilera et al. 2013a, b). In the present work, we combined information from those reviews with data on agricultural management obtained from interviews, conversion factors from LCA databases and the literature and IPCC emission factors to compare for the first time the full greenhouse gas emissions balance, or carbon footprint, of a representative sample of Spanish herbaceous crops under conventional and organic management. We calculated the balances according to LCA procedures, with the following objectives:

1. Determine the influence of organic management on area-based and product-based greenhouse gas balance of a range of herbaceous crops representing organic production in Spain

2. Identify critical processes in the carbon footprint of organic and conventional Mediterranean cropping systems and crop products
3. Analyze the effect of $\mathrm{N}_{2} \mathrm{O}$ emission factor choice and coproduct consideration (allocation and system expansion) in the estimation of the carbon footprint of the main product

4. Identify critical options for improving the carbon footprint of organic and conventional Mediterranean cropping systems and crop products

\section{Materials and methods}

\subsection{Data collection}

Information on management and production features was obtained from personal interviews to a representative sample composed of 38 pairs of organic and conventional farmers in Spain (Alonso and Guzmán 2010). The database was composed by 18 crop species, grouped by five crop types: rainfed cereals, including barley (four pairs of interviews), wheat (three) and oats (one); rainfed legumes, including peas (four), fava beans (one), and vetch (one); rice (three pairs); horticultural open air (Fig. 1), including asparagus (one), lettuce (two), melon (two), celery (one), cauliflower (one), potato (one), broccoli (one), onions (two), and beans (two); and horticultural greenhouse, including cherry tomato (one), tomato (four), lettuce (one), pepper (one), and beans (one).

\subsection{LCA scope}

An attributional LCA was performed based on the "cradle-tofarm gate" perspective, which considers all inputs and processes for the plant production as well as all the necessary upstream processes. In particular, the following processes were included within system boundaries: manufacturing and maintenance of machinery, fuel production and combustion, greenhouse infrastructure, fertilizer manufacturing, pesticide production, soil $\mathrm{N}_{2} \mathrm{O}$ emissions, indirect $\mathrm{N}_{2} \mathrm{O}$ emissions, $\mathrm{N}_{2} \mathrm{O}$ and $\mathrm{CH}_{4}$ emissions from open biomass burning, $\mathrm{CH}_{4}$ emissions from rice paddies, and soil $\mathrm{C}$ balance. The temporal boundaries were adjusted to 100 years, and all emissions were converted to $\mathrm{CO}_{2}$ equivalents using IPCC (2006) coefficients. Emissions associated to manure production were excluded from system boundaries, considering that they belong to the animal production systems (Nemecek et al. 2011; Venkat 2012).

Both 1 ha of cultivated land and $1 \mathrm{~kg}$ of marketed product were chosen as functional units. Some of the studied cropping systems produced coproducts in addition to the main marketable product, specifically legumes and cereals. These coproducts can be either unused (burned, landfilled), reused (incorporated to the soil), or extracted as additional products for feed or energy valorization (the latter not widespread now). As 
cereal and legume straw are mainly used for animal production as feed and bedding material, this coproduct was included in the impact assessment through economic allocation. IPCC (2006) Tier 1 methodology was used for the calculation the change in $\mathrm{CH}_{4}$ emissions resulting from the substitution of cereal grains by straw. Vegetable residues were considered as waste products, and no emissions were allocated to them.

\subsection{Carbon footprint method}

\subsubsection{Emissions from the production of inputs}

Data on machinery, fuel and electricity consumption, and greenhouse infrastructure material requirements were estimated as described by Alonso and Guzmán (2010). According to this procedure, the resource consumption of machinery and implements is attributable to four factors: production of raw materials, manufacture, repair and maintenance, and fuel consumption. In this work, we included minor changes in the calculation of fuel consumption. In particular, a load ratio of 75:45\% was taken for light duties (atomizing, spraying, bar rolling, and hydraulic sweeper). Emissions associated to the production of most inputs from the technosphere, such as machinery, pesticides, and some fertilizers were modeled using databases contained in SimaPro 7.2 software (PRé Consultants 2010), including ecoinvent 2.0 (ecoinvent Centre 2007) and LCA Food DK (Nielsen et al. 2003) with preference given to ecoinvent 2.0 database. Pesticides were differentiated by compound, family or broad type depending on information availability. Specific Spanish emission factors (Lago et al. 2013) were used for major NPK fertilizers, including ammonium nitrate, ammonium sulfate, ammonium nitrosulfate, urea, $\mathrm{N}$ in compound fertilizers, $\mathrm{K}_{2} \mathrm{O}$, and $\mathrm{P}_{2} \mathrm{O}_{5}$. Vermicompost emissions were calculated by scaling compost emissions from ecoinvent by the relative $\mathrm{N}$ content. Likewise, the $\mathrm{N}$-scaled ecoinvent emission value for dried poultry manure was taken for all granulated organic fertilizers. $\mathrm{N}$ contents of the organic fertilizers were $2.2,0.7,0.6$, and $1.1 \%$ for vermicompost, sheep manure, cow manure, and chicken manure. Fertilizers were assumed to be transported to the farm by lorry of $>16 t$ from distances of $300 \mathrm{~km}$ (synthetic fertilizers) and $30 \mathrm{~km}$ (organic fertilizers).

Electricity used in irrigation was assumed to come from the 2004 Spanish grid, as modeled in ecoinvent database, and to be half medium voltage and half low voltage. Emission values associated to irrigation infrastructure in the farm were taken from Lal (2004), distinguishing surface irrigation with and without recirculation system, sprinkler, and trickle irrigation systems.
Emissions associated to seed production were estimated using the grain emission factors obtained in the present study. This approach implies a self-reference in emission factor calculations, which was solved by iteration of the function until the result stabilized. One emission factor for conventional management and another for organic management were derived for seeds of rainfed cereals, rainfed legumes, and rice. In the case of organic management, some of the seed was not of organic origin. This proportion of conventional seed in organic systems was taken into account using Andalusian data from RAS (2006). Andalusia is the largest organic producing region in Spain, representing about half of the certified organic area in the country (MAGRAMA 2011). In order to make the results easier to visualize, all the seed was assumed to be bought in the marked, despite self-production is quite extended in organic farms (RAS 2006). This choice did not influence the results (data not shown). The impacts of vegetable seedling production were estimated based on peat consumption, assuming that the carbon content in peat was $55 \mathrm{~kg} \mathrm{~m}^{-3}$ (Hall 2006); that the peat volume used per seedling was $6-40 \mathrm{~cm}^{3}$, depending on crop species; and that all peat carbon was ultimately released to the atmosphere.

\subsubsection{Production and destinies of crop residues}

Residual biomass production quantities (straw and other crop residues) were estimated using yield information obtained from the interviews, and residue indexes were taken from Guzmán et al. (2014). The only information on residue management available in the interviews referred to the cases in which it was mulched and incorporated to the soil. In the remaining cases, burning rates of $1.2 \%$ for cereal straw, $20 \%$ for legume straw (fava beans and dry peas), $20 \%$ for vegetables, and $50 \%$ for potatoes were obtained from the National Spanish Emission Inventory (MARM 2010).

\subsubsection{Direct field emissions}

$\mathrm{N}_{2} \mathrm{O}$ emissions were estimated based on $\mathrm{N}$ inputs in the form of organic and synthetic fertilizers and agricultural residues. $\mathrm{N}$ content in the residues was obtained from López et al. (2005) (grain crops) and Rahn and Lillywhite (2002) (vegetables). Following IPCC (2006) guidelines, $\mathrm{N}$ released from soils with diminishing soil organic $\mathrm{C}$ stocks was also accounted as an input for $\mathrm{N}_{2} \mathrm{O}$ emission estimation, assuming a $\mathrm{C} / \mathrm{N}$ ratio in soil organic matter of 10:1. Direct $\mathrm{N}_{2} \mathrm{O}$ emissions were calculated using specific Mediterranean factors adjusted to irrigation type (Aguilera et al. 2013a): 0.08, 0.66, and $1.01 \%$ of applied $\mathrm{N}$ emitted as $\mathrm{N}_{2} \mathrm{O}-\mathrm{N}$ for rainfed, drip irrigation, and high-water irrigation systems, respectively. These factors are the means of all published information compiled by Aguilera et al. (2013a). IPCC (2006) emission factor of $0.3 \%$ was assumed for rice systems. In cereal and vegetable systems, 
Mediterranean factors were compared through a sensitivity analysis with IPCC factor of $1 \%$. The influence of applying a reduction of $20 \%$ in the emission factor of solid organic fertilizers was also studied in the sensitivity analysis, as $\mathrm{N}_{2} \mathrm{O}$ emissions associated to organic fertilizers could be lower than those of synthetic ones under Mediterranean conditions (Aguilera et al. 2013a). Indirect emissions were estimated using IPCC (2006) Tier 1 methodology, obtaining a $\mathrm{N}_{2} \mathrm{O}$ indirect emission factor of $0.4 \% \mathrm{~N}_{2} \mathrm{O}-\mathrm{N}$ per kilogram of $\mathrm{N}$ applied for synthetic fertilizers and $0.5 \%$ for organic ones. Emissions of $\mathrm{N}_{2} \mathrm{O}$ and $\mathrm{CH}_{4}$ from biomass burning were calculated following IPCC (2006) Tier 1 methodology.

$\mathrm{CH}_{4}$ emissions from rice cultivation were estimated following IPCC (2006) Tier 1 guidelines, considering continuous flooding during cultivation and a non-flooding period of $<180$ days previous to cultivation, and accounting for the amounts of rice straw (applied long before cultivation), weeds, and manure applied to the soil.

\subsubsection{Carbon sequestration}

In Aguilera et al. (Accepted), we developed a simple model for the calculation sequestration rates based on specific information from Mediterranean cropping systems. Soil $\mathrm{C}$ was assumed to be in equilibrium in conventional systems with no organic inputs and conventional tillage, and carbon inputs influenced the balance according to experimental values, which were modified to account for a 100-year time horizon. In this work, we adjusted the model to the particularities of herbaceous crops, taking into account the effect of tillage in herbaceous systems, the presence of $\mathrm{N}$ inputs in any form, and the presence of $\mathrm{C}$ inputs in the form of straw and weeds. C content of residues was obtained from Rahn and Lillywhite (2002). We assumed that full tillage was the reference practice, with no associated changes in soil carbon, while no tillage was associated to a net sequestration of $0.15 \mathrm{Mg} \mathrm{C}$ per hectare per year. This value is the average effect between no tillage and full tillage in the cases with similar $\mathrm{C}$ inputs in the meta-analysis by Aguilera et al. (2013b). Using the same source, the absence of some kind of $\mathrm{N}$ input in herbaceous systems was associated to a net emission of $0.48 \mathrm{Mg} \mathrm{C}$ per hectare. We considered that $8.5 \%$ of straw C was incorporated into the soil at a 100-year time horizon using data from other studies under Mediterranean conditions (Alvaro-Fuentes and Paustian 2011; Kong et al. 2005). Organic farms usually produce more weed biomass than conventional ones (Guzmán et al. 2014). This difference was considered as an additional $\mathrm{C}$ input to organic systems (Table 1).

\subsection{Sensitivity analysis}

We performed sensitivity analyses of the effects of using different $\mathrm{N}_{2} \mathrm{O}$ emission factors in cereals and open-air vegetables and of applying different methods of allocation and system expansion for coproduct consideration in cereals (Fig. 1). Nitrous oxide scenarios are compared to Base, which represents base case sequestration using Mediterranean factors, and include a scenario based on IPCC Tier 1 methodology (IPCC) and another with a $20 \%$ reduction in the emission factor of organic fertilizers (Reduction).

In a sensitivity analysis of cereal grain production, we compared economic allocation applied in the base case with different methods for coproduct consideration, including allocation and system expansion methods. Coproduct scenarios include the base case scenario (Economic); product allocation (Product), in which all emissions are allocated to the main product; dry matter allocation (Dry matter); and system expansion, in which coproduced straw is assumed to substitute cereal grain for cattle feeding. In Expansion 1, emissions from replaced grain production, calculated by the metabolizable energy content of each feedstock, are subtracted from product emissions. In Expansion 2, the change in enteric $\mathrm{CH}_{4}$ emissions due to the increase in straw in ruminant diet is also considered, following IPCC (2006) methodology based on total energy intake and feed digestibility.

\section{Results and discussion}

\subsection{The greenhouse gas profiles of the studied systems}

The studied categories are composed by heterogeneous cases, including different crop types, study sites, and management characteristics. This is reflected in the high variability of yields and carbon footprints that can be observed in Tables 1 and 2 . Therefore, the results presented herein must be taken with care. Nonetheless, certain clear trends can be identified between categories, and the pairwise selection of organic and conventional study cases reduces the influence of external factors on the estimated carbon footprints.

\subsubsection{Rainfed grains}

Because of the low $\mathrm{N}_{2} \mathrm{O}$ emission factor in rainfed Mediterranean cropping systems, the role of this gas was very limited in rainfed cereals, while the production and use of industrial inputs account for a major share of the emission profile. These inputs were mainly composed of machinery and fuel in the case of organic management, with a higher contribution of fertilizers in the case of conventional management (Fig. 2a). Interestingly, average $\mathrm{C}$ sequestration was not higher 
Table 1 Main characteristics of the life cycle inventory of the studied conventional (Con) and organic (Org) groups of herbaceous crops in Spain

\begin{tabular}{|c|c|c|c|c|c|c|c|c|c|c|}
\hline \multirow[b]{2}{*}{ Number of interviews } & \multicolumn{2}{|c|}{ Rainfed cereals } & \multicolumn{2}{|c|}{ Rainfed legumes } & \multicolumn{2}{|l|}{ Rice } & \multicolumn{2}{|c|}{ Open-air vegetables } & \multicolumn{2}{|c|}{ Greenhouse vegetables } \\
\hline & $\begin{array}{l}\text { Con } \\
8\end{array}$ & $\begin{array}{l}\text { Org } \\
8\end{array}$ & $\begin{array}{l}\text { Con } \\
6\end{array}$ & $\begin{array}{l}\text { Org } \\
6\end{array}$ & $\begin{array}{l}\text { Con } \\
3\end{array}$ & $\begin{array}{l}\text { Org } \\
3\end{array}$ & $\begin{array}{l}\text { Con } \\
13\end{array}$ & $\begin{array}{l}\text { Org } \\
13\end{array}$ & $\begin{array}{l}\text { Con } \\
8\end{array}$ & $\begin{array}{l}\text { Org } \\
8\end{array}$ \\
\hline \multicolumn{11}{|l|}{ Inputs } \\
\hline Drip irrigation (\%) & 0 & 0 & 0 & 0 & 0 & 0 & 54 & 54 & 100 & 100 \\
\hline Surface irrigation (\%) & 0 & 0 & 0 & 0 & 100 & 100 & 38 & 38 & 0 & 0 \\
\hline Water use $\left(\mathrm{m}^{3}\right)$ & 0 & 0 & 0 & 0 & 11,500 & 11,500 & 3677 & 3677 & 3613 & 3613 \\
\hline Electricity (kWh) & 0 & 0 & 0 & 0 & 3634 & 3634 & 1162 & 1162 & 1141 & 1141 \\
\hline Seeds (kg) & 183 & 173 & 182 & 192 & 215 & 235 & 0 & 0 & 0 & 0 \\
\hline Seedlings (1000 units) & 0.00 & 0.00 & 0.00 & 0.00 & 0.00 & 0.00 & 42.55 & 40.70 & 31.90 & 32.22 \\
\hline Machinery use (h) & 8 & 6 & 6 & 5 & 12 & 10 & 27 & 20 & 35 & 36 \\
\hline Fuel consumption (1) & 135 & 109 & 108 & 93 & 211 & 194 & 269 & 219 & 298 & 281 \\
\hline Mulching plastic (kg) & 0 & 0 & 0 & 0 & 0 & 0 & 35 & 11 & 185 & 168 \\
\hline Mineral nitrogen $(\mathrm{kg} \mathrm{N})$ & 73 & 0 & 13 & 0 & 152 & 0 & 104 & 0 & 264 & 0 \\
\hline Mineral phosphorus $\left(\mathrm{kg} \mathrm{P}_{2} \mathrm{O}_{5}\right)$ & 38 & 0 & 21 & 0 & 19 & 0 & 54 & 0 & 190 & 0 \\
\hline Mineral potassium $\left(\mathrm{kg} \mathrm{K}_{2} \mathrm{O}\right)$ & 34 & 0 & 23 & 0 & 19 & 0 & 141 & 3 & 292 & 0 \\
\hline Manure (Mg) & 0.00 & 1.43 & 0.00 & 0.72 & 0.00 & 7.67 & 5.08 & 18.08 & 7.00 & 13.75 \\
\hline Slurry (Mg) & 3.13 & 0.00 & 0.00 & 0.00 & 0.00 & 0.00 & 0.00 & 0.00 & 0.00 & 0.00 \\
\hline Other organic fertilizers $(\mathrm{kg})$ & 0 & 0 & 0 & 0 & 0 & 0 & 1 & 6 & 63 & 1103 \\
\hline Total carbon inputs (kg) & 108 & 577 & 407 & 532 & 2233 & 3171 & 690 & 3182 & 1546 & 2736 \\
\hline Total nitrogen inputs $(\mathrm{kg})$ & 87 & 17 & 61 & 50 & 177 & 90 & 162 & 167 & 393 & 155 \\
\hline Synthetic pesticides (kg active matter) & 0.43 & 0.00 & 0.91 & 0.00 & 7.14 & 0.00 & 5.46 & 0.00 & 52.36 & 0.00 \\
\hline Sulfur (kg) & 1.56 & 0.00 & 0.00 & 0.00 & 0.00 & 0.00 & 2.31 & 0.23 & 3.00 & 42.78 \\
\hline Copper (kg) & 0.00 & 0.00 & 0.00 & 0.00 & 0.33 & 0.00 & 3.02 & 0.20 & 3.45 & 2.15 \\
\hline Natural pesticides (kg) & 0.00 & 0.00 & 0.00 & 0.00 & 0.23 & 0.31 & 0.00 & 3.95 & 0.00 & 29.44 \\
\hline Steel $(\mathrm{kg})$ & 0 & 0 & 0 & 0 & 0 & 0 & 0 & 0 & 411 & 411 \\
\hline Greenhouse cover plastic (kg) & 0 & 0 & 0 & 0 & 0 & 0 & 0 & 0 & 1208 & 1208 \\
\hline Concrete $(\mathrm{kg})$ & 0 & 0 & 0 & 0 & 0 & 0 & 0 & 0 & 7290 & 7290 \\
\hline \multicolumn{11}{|l|}{ Production } \\
\hline Yield (Mg fresh matter, mean) & 2.95 & 1.95 & 2.32 & 1.32 & 7.50 & 5.17 & 23.37 & 17.48 & 66.23 & 47.96 \\
\hline Yield (Mg fresh matter, standard deviation) & 1.57 & 0.62 & 0.92 & 0.65 & 0.50 & 0.76 & 16.31 & 14.67 & 29.71 & 17.42 \\
\hline Yield (Mg dry matter, mean) & 2.54 & 1.68 & 1.99 & 1.13 & 6.48 & 4.46 & 2.48 & 1.93 & 3.66 & 2.75 \\
\hline Weeds (Mg dry matter) & 0.39 & 0.67 & 0.39 & 0.67 & 0.30 & 0.64 & 0.00 & 2.00 & 0.00 & 2.00 \\
\hline Residue yield (Mg dry matter) & 3.26 & 2.15 & 3.23 & 1.81 & 8.19 & 5.64 & 3.08 & 2.32 & 9.55 & 7.28 \\
\hline \multicolumn{11}{|l|}{ Residue destiny } \\
\hline Open burning (Mg) & 0.04 & 0.02 & 0.45 & 0.21 & 2.73 & 0.00 & 1.11 & 0.30 & 1.35 & 1.27 \\
\hline Soil incorporation $(\mathrm{Mg})$ & 0.19 & 0.73 & 0.99 & 0.76 & 5.46 & 5.64 & 0.65 & 1.16 & 2.81 & 0.93 \\
\hline Coproduct (Mg) & 3.03 & 1.40 & 1.79 & 0.83 & 0.00 & 0.00 & 0.00 & 0.00 & 0.00 & 0.00 \\
\hline Allocation to coproduct (\%) & 13 & 9 & 8 & 8 & 0 & 0 & 0 & 0 & 0 & 0 \\
\hline \multicolumn{11}{|l|}{ Soil emissions } \\
\hline Direct nitrous oxide $\left(\mathrm{kg} \mathrm{N}_{2} \mathrm{O}\right)$ & 0.11 & 0.02 & 0.03 & 0.02 & 0.84 & 0.42 & 1.84 & 1.98 & 4.03 & 1.56 \\
\hline Indirect nitrous oxide $\left(\mathrm{kg} \mathrm{N}_{2} \mathrm{O}\right)$ & 0.57 & 0.14 & 0.18 & 0.12 & 1.15 & 0.71 & 1.07 & 1.27 & 2.64 & 1.18 \\
\hline Methane $(\mathrm{kg} \mathrm{CH})_{4}$ & 0.10 & 0.05 & 1.21 & 0.56 & 347.60 & 440.60 & 3.00 & 0.81 & 3.64 & 3.43 \\
\hline Carbon (kg C) & -60 & -55 & -69 & -100 & -381 & -633 & -180 & -740 & -352 & -654 \\
\hline
\end{tabular}

Data refer to 1 ha per year unless otherwise stated

under organic than under conventional management, despite greater average $\mathrm{C}$ inputs, mainly in the form of crop residues. This could happen because there was one organic case with no organic inputs, and subsequently with a high $\mathrm{C}$ loss from the soil, according to our model. The net area-based global warming potential was $1024 \mathrm{~kg} \mathrm{CO} \mathrm{CO}_{2} \mathrm{e}$ per hectare of 


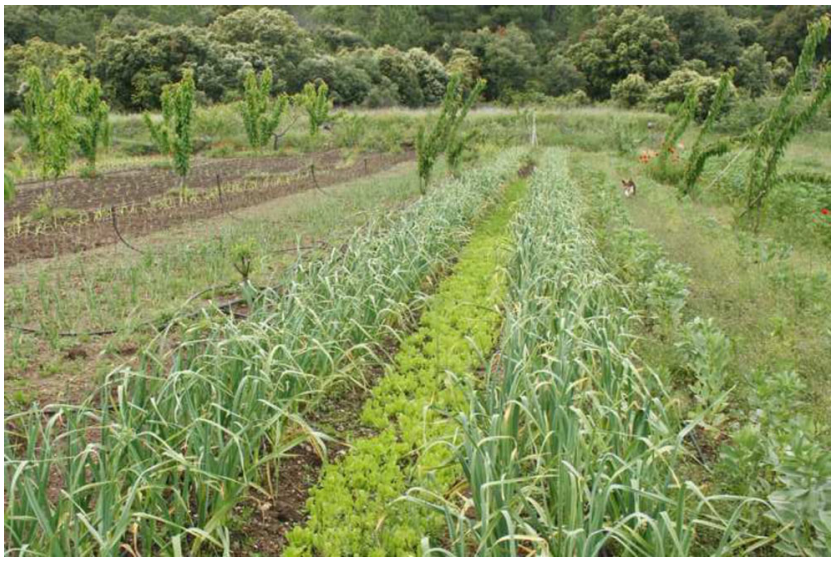

Fig. 1 Organic open-air vegetable cultivation in South Spain

conventional cereal, in comparison with $361 \mathrm{~kg}$ per hectare of organic cereal (Table 2), with an average decrease of $65 \%$ for organic products. The change was reduced to $-42 \%$ on a product basis due to lower yields under organic management, with emission values of 318 and $185 \mathrm{~g} \mathrm{CO} 2 \mathrm{e}$ per kilogram of conventional and organic product, respectively. The production of fertilizers was the main factor responsible for the differences observed, while $\mathrm{C}$ sequestration was similar between both types of management on an area basis. Our results for conventional grain production are in the lower range of global estimations by Nemecek et al. (2012) and in accordance with studies under Mediterranean climate such as that of Biswas et al. (2008).

Legumes are usually cultivated in rotation with cereals, and their management is similar to theirs in very aspects, particularly machinery use (Table 1). The low use of synthetic inputs under conventional legume management makes it relatively similar to organic legume management in terms of the composition and net value of the greenhouse gas emission balance (Fig. 2), with a modest change of $-16 \%$ in $\mathrm{CO}_{2} \mathrm{e}$ emissions per kilogram under organic management. Emission values per kilogram of conventional and organic legumes, of 233 and $195 \mathrm{~g}$ $\mathrm{CO}_{2} \mathrm{e}$, respectively, are $60-80 \%$ lower than those of different legumes reported in ecoinvent for different European sites (Nemecek et al. 2007). These low emission values support the extended use of legumes in Mediterranean arable crop rotations, adding to their key role as $\mathrm{N}$-fixers and protein suppliers.

\subsubsection{Rice}

Rice emissions are dominated by methane, with a significant contribution of irrigation (Fig. 2a). The relative performance of organic management in rice systems was the poorest among all crop types considered, mainly due to high methane emissions and low yields. Area-based global warming potential was $9 \%$ higher, but the differences were more marked on a product basis, with an average increase of $60 \%$ (1658 and $2650 \mathrm{~g} \mathrm{CO}_{2} \mathrm{e}$ per kilogram of conventional and organic rice, respectively). Increased methane emissions in organic systems were associated to the incorporation of rice straw and manures. As shown in other studies, $C$ sequestration promoted by these inputs could not overcome the increase in methane emissions in terms of global warming potential (Wang et al. 2012). Straw and manure have a high content of easily decomposable $\mathrm{C}$, which is associated to methane emissions in rice paddies and therefore to a high scaling factor according to IPCC (2006) methodology. Conventional rice emissions are in the lower range of the global estimations reported by Nemecek et al. (2012), while organic rice emissions are in the upper range.

\subsubsection{Vegetables}

Irrigation in Mediterranean vegetable cropping systems implies high energy consumption and associated emissions for water pumping and infrastructure building (Table 1), but also allows for higher response to, and thus higher use of fertilizers and pesticides, whose importance in the greenhouse gases emissions balance grows at the expense of machinery emissions (Fig. 2a). The observed decrease in emissions per hectare in organic vegetable cropping systems $(-59 \%$ change on average) was due to lower emissions associated to fuel use, fertilizer and pesticide production, and a nearly threefold increase in $\mathrm{C}$ sequestration (Table 2). When studied per kilogram of product, organic emissions were still lower in 12 out of the 13 cases studied, with an average change of $-32 \%$ (238 and $161 \mathrm{~g} \mathrm{CO}_{2} \mathrm{e}$ per kilogram of conventional and organic product, respectively). The reduction occurred despite increased $\mathrm{N}_{2} \mathrm{O}$ emissions per hectare due to higher indirect $\mathrm{N}_{2} \mathrm{O}$ emission factor for organic fertilizers. This could happen because fertilizer intensification in the studied organic systems promotes soil $\mathrm{C}$ sequestration through the increase in $\mathrm{C}$ inputs and maintains low emission levels in the production of fertilizers, as it mainly employs organic waste materials. The observed global warming potential for conventional systems agrees with assessments performed in many other conditions (González et al. 2011; Nemecek et al. 2012) including a study under Mediterranean climate in California (Venkat 2012). Therefore, differences with other climates seem to be less marked for irrigated Mediterranean systems than for rainfed ones.

Emissions in greenhouse cropping systems were dominated by greenhouse infrastructure (41 and $59 \%$ of emissions in conventional and organic systems, as average), as was also observed in the energy balance of the same crops (Alonso and Guzmán 2010). Emissions in greenhouse cropping systems were relatively high per hectare and low per kilogram of product in both types of management, due to input intensification and high yields. We observed that the average differences in the net global warming potential between organic and 
Table 2 Global warming potential of organic and conventional Spanish herbaceous cropping systems for a 100-year time horizon expressed as kilograms of $\mathrm{CO}_{2} \mathrm{e}$ per hectare per year and as grams of $\mathrm{CO}_{2} \mathrm{e}$ per kilogram of product

\begin{tabular}{|c|c|c|c|c|c|c|c|c|c|c|}
\hline & \multicolumn{2}{|c|}{ Rainfed cereals } & \multicolumn{2}{|c|}{ Rainfed legumes } & \multicolumn{2}{|l|}{ Rice } & \multicolumn{2}{|c|}{ Open-air vegetables } & \multicolumn{2}{|c|}{ Greenhouse vegetables } \\
\hline & Con & Org & Con & Org & Con & Org & Con & Org & Con & Org \\
\hline \multicolumn{11}{|c|}{ Area-based emissions $\left(\mathrm{kg} \mathrm{CO}_{2} \mathrm{e} \mathrm{ha}^{-1}\right)$} \\
\hline Machinery production & 28 & 22 & 21 & 19 & 45 & 42 & 52 & 43 & 64 & 56 \\
\hline Fuel production & 58 & 47 & 47 & 40 & 91 & 84 & 116 & 95 & 129 & 122 \\
\hline Fuel use & 364 & 294 & 290 & 251 & 569 & 523 & 725 & 591 & 804 & 758 \\
\hline Fertilizer production & 410 & 5 & 183 & 3 & 521 & 29 & 792 & 73 & 2364 & 216 \\
\hline Direct nitrous oxide & 33 & 6 & 10 & 6 & 249 & 126 & 547 & 591 & 1202 & 465 \\
\hline Indirect nitrous oxide & 170 & 41 & 54 & 35 & 344 & 210 & 318 & 378 & 787 & 352 \\
\hline Pesticides & 3 & 0 & 9 & 0 & 81 & 3 & 58 & 12 & 362 & 91 \\
\hline Irrigation infrastructure & 0 & 0 & 0 & 0 & 90 & 90 & 206 & 206 & 311 & 311 \\
\hline Irrigation energy & 0 & 0 & 0 & 0 & 2018 & 2018 & 645 & 645 & 634 & 634 \\
\hline Methane & 2 & 1 & 30 & 14 & 8690 & 11,015 & 75 & 20 & 91 & 86 \\
\hline Greenhouse & 0 & 0 & 0 & 0 & 0 & 0 & 0 & 0 & 5157 & 5157 \\
\hline Nursery & 65 & 46 & 42 & 44 & 343 & 501 & 146 & 135 & 164 & 166 \\
\hline Carbon & -110 & -102 & -127 & -184 & -699 & -1160 & -330 & -1399 & -645 & -1199 \\
\hline Total (mean) & 1024 & 361 & 568 & 232 & 12,401 & 13,481 & 3448 & 1418 & 11,841 & 7592 \\
\hline Total (standard deviation) & 432 & 394 & 287 & 157 & 1751 & 208 & 1633 & 557 & 5216 & 1150 \\
\hline \multicolumn{11}{|c|}{ Product-based emissions $\left(\mathrm{g} \mathrm{CO}_{2} \mathrm{e} \mathrm{kg}^{-1}\right.$ ) } \\
\hline Machinery production & 10 & 11 & 9 & 15 & 6 & 8 & 4 & 5 & 1 & 1 \\
\hline Fuel production & 22 & 24 & 21 & 32 & 12 & 17 & 9 & 12 & 2 & 3 \\
\hline Fuel use & 137 & 152 & 131 & 202 & 76 & 103 & 55 & 77 & 14 & 17 \\
\hline Fertilizer production & 117 & 2 & 63 & 3 & 70 & 6 & 46 & 7 & 34 & 5 \\
\hline Direct nitrous oxide & 10 & 3 & 4 & 4 & 33 & 26 & 31 & 47 & 19 & 10 \\
\hline Indirect nitrous oxide & 54 & 19 & 22 & 25 & 46 & 43 & 23 & 37 & 12 & 8 \\
\hline Pesticides & 1 & 0 & 3 & 0 & 11 & 1 & 3 & 1 & 5 & 2 \\
\hline Irrigation infrastructure & 0 & 0 & 0 & 0 & 12 & 18 & 23 & 31 & 7 & 8 \\
\hline Irrigation energy & 0 & 0 & 0 & 0 & 270 & 396 & 58 & 73 & 10 & 13 \\
\hline Methane & 1 & 0 & 11 & 11 & 1161 & 2164 & 7 & 2 & 2 & 2 \\
\hline Greenhouse & 0 & 0 & 0 & 0 & 0 & 0 & 0 & 0 & 109 & 126 \\
\hline Nursery & 21 & 21 & 19 & 35 & 47 & 91 & 5 & 8 & 3 & 4 \\
\hline Carbon & -58 & -50 & -54 & -135 & -93 & -228 & -34 & -144 & -12 & -27 \\
\hline Total (mean) & 315 & 183 & 233 & 195 & 1660 & 2644 & 238 & 161 & 215 & 178 \\
\hline Total (standard deviation) & 88 & 219 & 94 & 125 & 258 & 415 & 196 & 176 & 113 & 66 \\
\hline Coproduct & 50 & 27 & 21 & 23 & 0 & 0 & 0 & 0 & 0 & 0 \\
\hline
\end{tabular}

conventional management were relatively small $(-17 \%$ on a product basis), which can be attributed to the high burden of greenhouse infrastructure and water consumption in these systems. The average emission values of 215 and $178 \mathrm{~g}$ $\mathrm{CO}_{2}$ e per kilogram of conventional and organic vegetables, respectively, confirm the relatively low carbon footprint of vegetable production in Mediterranean greenhouses obtained in other studies, as compared to vegetables cultivated in heated, glass built greenhouses in colder regions (Theurl et al. 2013; González et al. 2011). We found no previous data reporting emissions of organic vegetables cultivated in Mediterranean greenhouses.
Quality differences should be taken into account when comparing organic and conventional vegetables, as higher dry matter content of organic products (Lester and Saftner 2011) may partially offset lower yields.

\subsection{Sensitivity analysis}

\subsubsection{Nitrous oxide emission factor}

The results showed a high variability in the response to the choice of $\mathrm{N}_{2} \mathrm{O}$ emission factor. The use of a reduced emission factor for organic fertilizers had an almost negligible effect on 
Fig. 2 Global warming potential $\left(\mathrm{g} \mathrm{CO}_{2} \mathrm{e} \mathrm{kg}^{-1}\right)$ of the five types of crop products and the two types of management (Conventional (Con) and organic (Org)) studied, expressed as the breakdown of the main processes implicated and as the net balance resulting from subtracting carbon sequestration to total emissions (means with standard errors). The components of the emission balance comprise Nursery, including seed production in grain crops and plant nursery in vegetables; $\mathrm{CH}_{4}$, methane from rice cultivation and biomass burning; Pesticide production; $\mathrm{N}_{2} \mathrm{O}$, including soil emissions, indirect emissions and biomass burning emissions of nitrous oxide; Fertilizers production and transport; Machinery production and use, including fuel production and use; and $S O C$, which accounts for the changes in soil organic carbon resulting from management practices

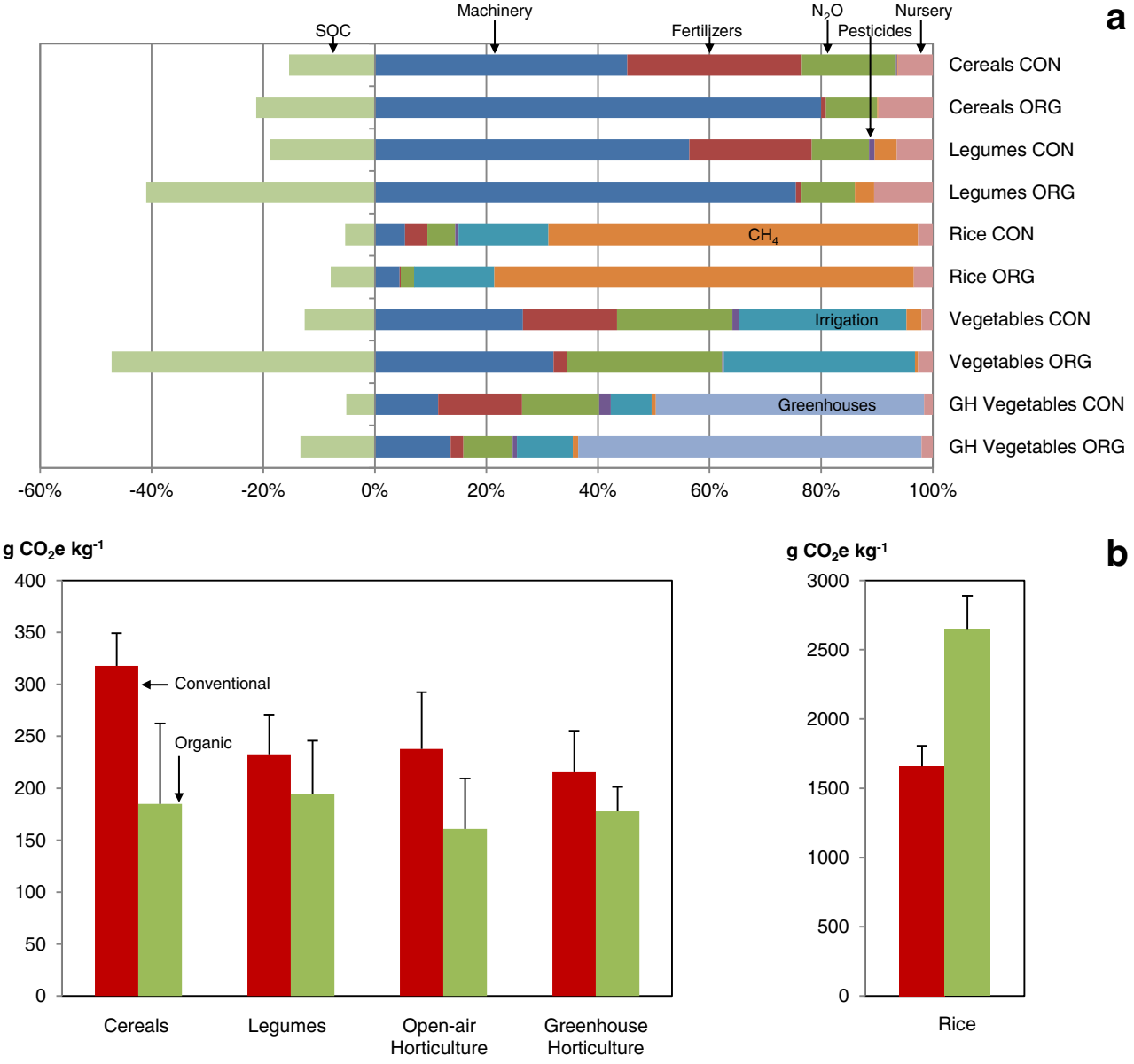

the global warming potential of the studied systems. By contrast, largest changes occurred when IPCC factor was used in conventional cereals, which increased net emissions by $33 \%$, as compared to only $18 \%$ in organic cereals (Fig. 3a). $\mathrm{N}_{2} \mathrm{O}$ emission in cereals were actually highly affected by the emission factor due to the large difference between Mediterranean rainfed factor and IPCC factor (one order of magnitude lower for Mediterranean), but in organic systems, the relative contribution of nitrous oxide to the total carbon footprint was small due to low rates of fertilizer application (Fig. 2a). In vegetables, the net effect of the change of $\mathrm{N}_{2} \mathrm{O}$ emission factor was much lower (Fig. 3b) because the Mediterranean factors for irrigated systems used in the base case were very similar to the IPCC factor (they were equal in the case of high-water irrigation and $30 \%$ lower for drip irrigation). Our results show that the use of climate-specific emission factors instead of IPCC Tier 1 factors for the estimation of $\mathrm{N}_{2} \mathrm{O}$ emissions in LCA of Mediterranean cropping systems leads to substantial differences in the net global warming potential, especially under rainfed conditions. These results agree with the LCA of rainfed cereal systems in Mediterranean-climate Western Australia performed by Biswas et al. (2008).

\subsubsection{Coproduct consideration}

The sensitivity test shown in Fig. 3c clearly indicates the relevance of the consideration of this coproduct in the greenhouse gas emission balance of cereal grains. The different methods compared address different research questions and lead to very different results. The results obtained using economic criteria for allocation (Economic), as in the base scenario, only slightly differed from those obtained allocating all emissions to the main product (Product), due to the low economic value of straw. When mass criteria were used (Dry matter), however, major changes in the estimated carbon footprint were observed, as the production of commercialized straw, in terms of dry matter, was similar to that of grain (Table 1). The largest effect of coproduct consideration was observed when the system was expanded. In Expansion 1 scenario, we subtracted the emissions associated to the production of the grains replaced by straw as animal feed. This resulted in the lowest global warming potential among the studied methodologies. Other studies have also shown that consequential LCAs usually yield lower global warming potential estimates than attributional LCAs (Thomassen et al. 2008). The observed reduction, however, was more than offset 


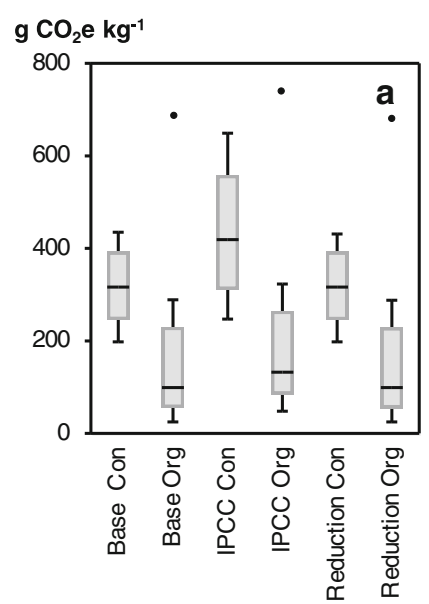

Fig. 3 Sensitivity analysis of the global warming potential $\left(\mathrm{g} \mathrm{CO}_{2} \mathrm{e} \mathrm{kg}^{-1}\right)$ of conventional (Con) and organic (Org) management as affected by different estimations of nitrous oxide emissions in cereals (a) and openair vegetables (b) and as affected by changes in coproduct consideration in cereals (c). Nitrous oxide scenarios are compared to Base, which represents base case sequestration using Mediterranean factors and include estimates using IPCC Tier 1 methodology (IPCC) and a $20 \%$ reduction in the emission factor of organic fertilizers (Reduction). Coproduct scenarios include product allocation (Product), in which all

by increased enteric $\mathrm{CH}_{4}$ emissions due to the use of a lower quality feed (Expansion 2). These results highlight the need for a full accounting of the effect of these destinies when studying the potential of straw for $\mathrm{C}$ sequestration or for other uses such as energy production. Our analysis suggests that complementing the attributional assessment of agricultural products with a consequential analysis would provide insights for understanding these trade-offs.

\subsection{The potential for mitigation in herbaceous systems}

As described in Sect. 3.1, most of the studied agricultural systems show relatively low emission levels, especially under organic management. The high variability observed, however, together with the limited extension of some climate-friendly practices, suggest that the potential for mitigation is still very large. A singular case is the high emission observed in organic rice production, whose reduction would probably benefit from the use of more stabilized organic inputs, such as compost, vermicompost, or digested slurries, as well as from the increase in yield performance and the reduction in flooding period and in non-renewable input use.

\subsubsection{Reducing fossil fuel-based inputs}

Fossil energy use dominated the greenhouse gas profiles of the studied systems. In rainfed systems, most emissions were produced by machinery and fuel use, plus fertilizer production

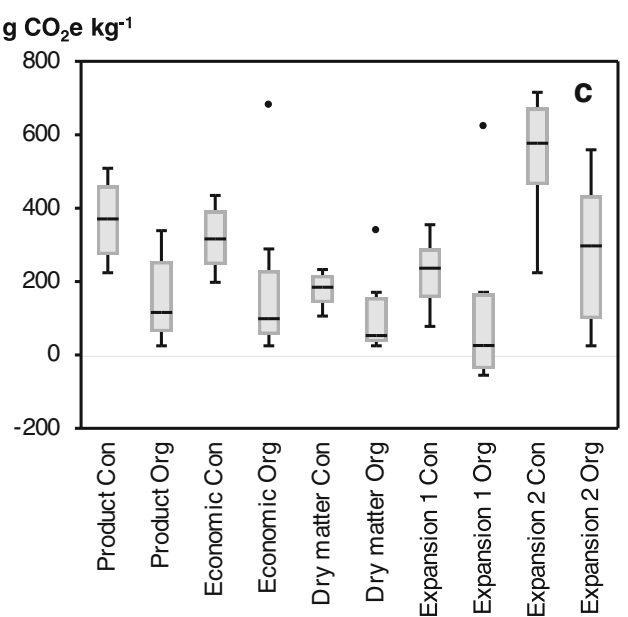

emissions are allocated to the main product; economic allocation (Economic); dry matter allocation (Dry matter); and system expansion, in which coproduced straw is assumed to substitute cereal grain for cattle feeding. In Expansion 1, emissions from replaced grain production are subtracted from product emissions, and in Expansion 2, the change in enteric $\mathrm{CH}_{4}$ emissions is also considered. Data are presented by medians (lines), 25-75\% percentiles (boxes), non-outlier ranges (whiskers), outliers (dots), and extremes (asterisks)

in the case of conventional systems. In irrigated systems, the emission profile was diversified by water extraction and greenhouse infrastructure, which are also based on fossil fuels. Fossil fuel-based inputs can be reduced through efficiency gains and through substitution by self-produced renewable ones. The first strategy could make use of techniques such as drip irrigation and reduced tillage practices. The second would imply the use of renewable energy in irrigation, such as solar or wind energy, and the self-production of the fuel used in the farm. Drip irrigation clearly appears as a win-win strategy, saving water and the energy needed for its extraction, while potentially lowering $\mathrm{N}_{2} \mathrm{O}$ emissions (Aguilera et al. 2013a). Our results show that the increased emissions due to drip irrigation infrastructure are clearly offset by the emission savings.

In mechanization-dominated rainfed systems, reduced tillage would promote $\mathrm{C}$ sequestration (Aguilera et al. 2013b) while saving fuel, cutting greenhouse gas emissions, and reducing the dependence on the increasingly scarce supply of oil derivatives. Tillage reduction often relies on chemical weed control, which may increase pesticide production emissions, but purely mechanical minimum tillage methods are also available. Fuel savings would also improve the feasibility of self-producing the fuel needed in the farm, as a smaller fraction of the product would be needed for producing the biofuel. Self-production of the fuel could increase the efficiency in the use of non-renewable energy while producing a protein-rich coproduct (Aguilera 2009). 


\subsubsection{Maximizing total yield}

Lower yields in organic systems were responsible for decreased carbon footprint reductions under organic farming when studied on a product basis instead of on an area basis. Increasing yields thus appears as a priority for the improvement of the environmental profile of organic cropping systems. Yield improvement would require solving problems associated to the management of pests, diseases, weeds, and nutrients. On the other hand, proposals for changes in management practices have to consider their full impacts. For example, weeds also contribute to the reduction of the net global warming potential by promoting carbon sequestration, as well as to pest control by the provision of habitats for biological control agents. Furthermore, in forage-oriented systems such as cereal and legume fields, the production of weeds may represent an additional forage output that could increase total forage yield when compared with weed-free monocultures (Gholamhoseini et al. 2013). Therefore, deriving weed management recommendations in relation with climate change mitigation is not straightforward and should take into account the multiple functions of weeds in cropping systems. A similar problem appears with the valorization of straw as an additional product. The direct utilization of straw for electricity or thermal energy production is gaining increasing interest (Nguyen et al. 2013), but our analysis suggests that the extraction of straw for energetic purposes should always consider the effect on other uses such as animal feeding and the needed straw to be retained for maintaining or increasing SOC balance. Hence, the revision of yield metrics to consider the multifunctionality of the primary production of cropping systems would contribute to a more accurate quantification of their yield-related environmental burdens, helping to reduce the land cost of sustainability (Guzmán et al. 2011). From this view, techniques that simultaneously address multiple functions seem the most interesting.

\subsubsection{Increasing carbon sequestration}

Our data suggest that enhancing $\mathrm{C}$ sequestration leads to climate change mitigation in Mediterranean systems, which usually show low $\mathrm{N}_{2} \mathrm{O}$ emissions and a high soil $\mathrm{C}$ response to organic inputs. On the other hand, our estimation of carbon sequestration is based on a 100year time horizon. Higher carbon sequestration rates, and thus a higher influence of carbon sequestration in the overall balance, would be occurring at a shorter time frames (i.e., 20 years), as shown in a sensitivity analysis of the carbon footprint of Spanish fruit tree orchards (Aguilera et al., Accepted).

Maximizing organic matter inputs both in organic and conventional systems is a way to achieve carbon sequestration that could help improving yields in the former, while reducing the need for synthetic fertilizers and their associated emissions in the latter. However, a number of factors limit endogenousbased $\mathrm{C}$ sequestration in herbaceous systems. A major structural limit is space availability for cultivating cover crops, as it would usually mean cultivating less commercial crops in the rotations. The majority of the potential for expanding cover crops relies in crop rotations including a year of fallow and in summer irrigated crops in which the soil is now left bare in the winter.

Another limitation to the increase in organic inputs for soil $\mathrm{C}$ sequestration is the alternative use of straws as animal feed. In a country such as Spain, highly dependent on feed imports (Lassaletta et al. 2014), straw may be playing an important role preventing the use of imported grains. Our calculations show that this replacement would have a larger effect on the carbon footprint of crop products than its application to soil. At the same time, increasing soil organic matter levels in Mediterranean soils may be key for adapting to climate change, due to its positive effect on soil physical properties (Aguilera et al. 2013b). This trade-off suggests that there is a need to ensure that the majority of the $\mathrm{C}$ removed with straw returns to the soil in some form. The transformation of plant biomass in ruminant bodies implies a release of $\mathrm{C}$ as $\mathrm{CO}_{2}$ and $\mathrm{CH}_{4}$, but could also contribute to stabilization of the $\mathrm{C}$ remaining in the manure, potentially resulting in similar soil retention of the original $\mathrm{C}$ with manures than with raw plant biomass (Thomsen et al. 2013). Accordingly, some studies have shown that grazing cereal stubble may not have detrimental effects on $\mathrm{C}$ stocks, at least under semi-arid conditions (Quiroga et al. 2009). In spite of this potential, however, the comparison of the global warming potential of these alternative uses of straw would also require considering $\mathrm{CH}_{4}$ and $\mathrm{N}_{2} \mathrm{O}$ emissions produced by animal raising and the potential of dietary changes for the reduction of the demand of meat.

\section{Conclusions}

Our analysis of the greenhouse gas emission profile of 38 pairs of conventional and organic herbaceous cropping systems in Spain shows that energy-related emissions are the main contributors to the net global warming potential of most of the studied systems, followed by $\mathrm{C}$ sequestration. The other soil emissions usually represent a minor role, especially in rainfed systems, which are dominated by fuel emissions. Relatively low $\mathrm{N}_{2} \mathrm{O}$ emissions under Mediterranean conditions, due to low $\mathrm{N}$ application rates and low $\mathrm{N}_{2} \mathrm{O}$ emission factors as compared to global IPCC (2006), are partially responsible for this. These data suggest that management recommendations for climate change mitigation should be based on comprehensive approaches to the quantification of 
agricultural greenhouse gases, including upstream life cycle processes and climate-specific calculations of direct field emissions and carbon sequestration.

Despite a high variability, we observed a general trend for lower greenhouse gases emissions under organic management, with the significant exception of rice, which represents a clear outlier in our analysis. Higher methane emissions under organic farming point at the convenience of using more stabilized organic inputs in organic rice systems. In the other systems, emission savings under organic farming were due to lower input use or higher $\mathrm{C}$ sequestration, or to the combination of both processes, and they were not fully offset by lower yields.

Our results show for the first time that Mediterranean conditions favor intensification in the application of organic matter inputs for climate change mitigation in rainfed and drip-irrigated systems, because the higher $\mathrm{C}$ sequestration and yields achieved are not accompanied by very high increases in $\mathrm{N}_{2} \mathrm{O}$ emissions. On the contrary, this effect is jeopardized by high fossil energy consumption in surface-irrigated systems and greenhouse systems. More research is needed to verify if similar patterns are found in other semi-arid climates. The dominance of non-renewable energy emissions in the global warming potential of the studied crop products suggests that strategies aiming to reduce resource consumption would successfully contribute to climate change mitigation. For instance, drip irrigation increases yield and residual biomass with low water use and $\mathrm{N}_{2} \mathrm{O}$ emissions. Non-renewable fuels could be substituted by self-produced ones, and irrigation water could be extracted with solar or wind energy.

Finally, our results underline the importance of the current and potential multifunctionality of coproducts in the greenhouse gases emissions balance of crop products. For example, the use of herbaceous residues and weeds as animal feed, ensuring that the manure is appropriately applied to the soil, could produce extra food with minor effects on soil $\mathrm{C}$ balance but also promotes $\mathrm{CH}_{4}$ emissions. Thus, this practice seems to be more resource efficient but may increase net greenhouse gases emissions as compared to directly incorporating those residues into the soil. In any case, the role of straw and weeds as ruminant feed needs to be taken into account in the assessment of alternative uses such as $\mathrm{C}$ sequestration or energy provision.

Acknowledgments This study was funded by the Canadian Social Sciences and Humanities Research Council through the project 895 2011-1020 Sustainable farm systems: long-term socio-ecological metabolism in western agriculture. We would like to thank Luis Lassaletta for his helpful comments.

\section{References}

Aguilera E (2009) Hacia la autosuficiencia energética en el cereal de secano. Un estudio de caso en Orce (Granada). Universidad Pablo de Olavide, Sevilla, Spain

Aguilera E, Lassaletta L, Gattinger A, Gimeno BS (2013a) Managing soil carbon for climate change mitigation and adaptation in Mediterranean cropping systems. A meta-analysis. Agric Ecosyst Environ 168:25-36. doi:10.1016/j.agee.2013.02.003

Aguilera E, Lassaletta L, Sanz-Cobena A, Garnier J, Vallejo A (2013b) The potential of organic fertilizers and water management to reduce $\mathrm{N}_{2} \mathrm{O}$ emissions in Mediterranean climate cropping systems. Agric Ecosyst Environ 164:32-52. doi:10.1016/j.agee.2012.09.006

Aguilera E, Guzmán GI, Alonso AM (Accepted) Greenhouse gas emissions from organic and conventional cropping systems in Spain. II. Fruit tree orchards. Agron Sustain Dev. doi:10.1007/s13593-014-0265-y

Alonso AM, Guzmán GI (2010) Comparison of the efficiency and Use of energy in organic and conventional farming in spanish agricultural systems. J Sustainable Agric 34:312-338. doi:10.1080/ 10440041003613362

Alvaro-Fuentes J, Paustian K (2011) Potential soil carbon sequestration in a semiarid Mediterranean agroecosystem under climate change: Quantifying management and climate effects. Plant Soil 338:261272. doi:10.1007/s11104-010-0304-7

Biswas WK, Barton L, Carter D (2008) Global warming potential of wheat production in Western Australia: a life cycle assessment. Water Environ J 22:206-216. doi:10.1111/j.1747-6593.2008. 00127.x

Cherubini F, Ulgiati S (2010) Crop residues as raw materials for biorefinery systems - a LCA case study. Appl Energy 87:47-57. doi:10.1016/j.apenergy.2009.08.024

Ecoinvent Centre (2007) Ecoinvent data v2.0. ecoinvent reports No. 125. Swiss Centre for Life Cycle Inventories, Dübendorf, Switzerland

FAO (2014) FAOSTAT Trade module. Part of FAOSTAT-FAO database for food and agriculture. Rome: Food and Agriculture Organisation of United Nations (FAO). http://faostat3.fao.org/ faostat-gateway/go/to/download/T/*/E. Accessed 15 Jan 2014

Gholamhoseini M, AghaAlikhani M, Mirlatifi SM, Sanavy SAMM (2013) Weeds - friend or foe? increasing forage yield and decreasing nitrate leaching on a corn forage farm infested by redroot pigweed. Agric Ecosyst Environ 179:151-162. doi:10. 1016/j.agee.2013.08.016

González AD, Frostell B, Carlsson-Kanyama A (2011) Protein efficiency per unit energy and per unit greenhouse gas emissions: potential contribution of diet choices to climate change mitigation. Food Policy 36:562-570. doi:10.1016/j.foodpol.2011.07.003

Guzmán GI, González de Molina M, Alonso AM (2011) The land cost of agrarian sustainability. An assessment. Land Use Policy 28:825835. doi:10.1016/j.landusepol.2011.01.010

Guzmán GI, Aguilera E, Soto Fernández D et al (2014) Working paper No. 2: Methodology and converters to calculate the net primary productivity (NPP) of the agro-ecosystems. Sociedad Española de Historia Agraria - Documentos de trabajo, DT-SEHA, 1407

Hall MJ (2006) A guide to calculating the carbon dioxide debt and payback time for wind farms. Foundation, Renewable Energy

IPCC (2006) Guidelines for National Greenhouse Gas Inventories vol. 4. Agriculture, Forestry and Other Land Use. Intergovernmental Panel on Climate Change, Japan

Kong AYY, Six J, Bryant DC et al (2005) The relationship between carbon input, aggregation, and soil organic carbon stabilization in sustainable cropping systems. Soil Sci Soc Am J 69:1078-1085. doi:10.2136/sssaj2004.0215

Lago C, Lechón Y, Herrera I, Sánchez J (2013) GHG emission factors for domestic consumption of fertilizers in Spain. II Remedia Workshop, Zaragoza, Spain 
Lal R (2004) Carbon emission from farm operations. Environ Int 30:981990. doi:10.1016/j.envint.2004.03.005

Lal R, Delgado JA, Groffman PM et al (2011) Management to mitigate and adapt to climate change. J Soil Water Conserv 66:276-285. doi: 10.2489/jswc.66.4.276

Lassaletta L, Billen G, Romero E et al (2014) How changes in diet and trade patterns have shaped the N cycle at the national scale: Spain. Reg Environ Chang 14:785-797. doi:10.1007/s10113-013-0536-1

Lester GE, Saftner RA (2011) Organically versus conventionally grown produce: common production inputs, nutritional quality, and nitrogen delivery between the two systems. J Agric Food Chem 59: 10401-10406. doi:10.1021/jf202385x

López MV, Arrúe JL, Álvaro-Fuentes J, Moret D (2005) Dynamics of surface barley residues during fallow as affected by tillage and decomposition in semiarid Aragon (NE Spain). Eur J Agron 23: 26-36. doi:10.1016/j.eja.2004.09.003

MAGRAMA (2011) Anuario de estadística agraria. Ministerio de Agricultura, Alimentación y Medio Ambiente, Madrid

MARM (2010) Inventario de emisiones de gases de efecto invernadero de España 1990-2008. Comunicación a la Comisión Europea. Ministerio de Medio Ambiente, Medio Rural y Marino, Madrid

Nemecek T, Heil A, Huguenin O et al (2007) Life cycle inventories of agricultural production systems. Swiss Centre for Life Cycle Inventories. Dübendorf, $\mathrm{CH}$

Nemecek T, Dubois D, Huguenin-Elie O, Gaillard G (2011) Life cycle assessment of Swiss farming systems: I. Integrated and organic farming. Agric Syst 104:217-232. doi:10.1016/j.agsy. 2010.10.002

Nemecek T, Weiler K, Plassmann K et al (2012) Estimation of the variability in global warming potential of worldwide crop production using a modular extrapolation approach. J Clean Prod 31:106117. doi:10.1016/j.jclepro.2012.03.005
Nguyen TLT, Hermansen JE, Mogensen L (2013) Environmental performance of crop residues as an energy source for electricity production: The case of wheat straw in Denmark. Appl Energy 104:633641. doi:10.1016/j.apenergy.2012.11.057

Nielsen PH, Nielsen AM, Weidema BP et al (2003) LCA food database. www.lcafood.dk. Accessed 10 Dec 2013

PRè Consultants (2010) SimaPro Life Cycle Analysis version 7.2 (software)

Quiroga A, Fernandez R, Noellemeyer E (2009) Grazing effect on soil properties in conventional and no-till systems. Soil Tillage Res 105: 164-170. doi:10.1016/j.still.2009.07.003

Rahn CR, Lillywhite RD (2002) A study of the quality factors affecting the short-term decomposition of field vegetable residues. J Sci Food Agric 82:19-26. doi:10.1002/jsfa.1003

RAS (2006) Estudio de la disponibilidad y demanda de semillas y material de reproducción vegetativa para la agricultura ecológica. Consejería de Agricultura y Pesca de la Junta de Andalucía, Sevilla, Spain.

Theurl MC, Haberl H, Erb K-H, Lindenthal T (2013) Contrasted greenhouse gas emissions from local versus long-range tomato production. Agron Sustain Dev 34:593-602. doi:10.1007/s13593-013-0171-8

Thomassen MA, Dalgaard R, Heijungs R, de Boer I (2008) Attributional and consequential LCA of milk production. Int J Life Cycle Assess 13:339-349. doi:10.1007/s11367-008-0007-y

Thomsen IK, Olesen JE, Møller HB et al (2013) Carbon dynamics and retention in soil after anaerobic digestion of dairy cattle feed and faeces. Soil Biol Biochem 58:82-87. doi:10.1016/j.soilbio.2012.11.006

Venkat K (2012) Comparison of twelve organic and conventional farming systems: a life cycle greenhouse gas emissions perspective. J Sustainable Agric 36:620-649. doi:10.1080/10440046.2012.672378

Wang J, Zhang X, Liu Y et al (2012) Modeling impacts of alternative practices on Net global warming potential and greenhouse Gas intensity from rice-wheat annual rotation in China. PLoS ONE 7: e45668. doi:10.1371/journal.pone.0045668 